\title{
Model Show Window for Raising Chrisanthenum Kulo and Riri based Information Technology as Tourism Destination in Town of Tomohon
}

Olga Melo

\author{
Tirone Tanod
}

\author{
Robby Tangkudung
}

\begin{abstract}
Tomohon is known as a city icon Flowers in North Sulawesi. Chrysanthemum coolies, FE and riri is local flower varieties developed by the community and the government of Tomohon. Development show window of two hectares in 2013 and 1.5 hectares will be built in 2015 on five hectares of land to be provided by the City Government of Tomohon. Show window was built as a showcase that Tomohon as the City of Flowers and used as a nursery site, learning, cultivation, kultut laboratory network and the deployment of flower production, as well as used as a tourist spot. Show Window will also become the center for the cultivation of chrysanthemums in the eastern part of Indonesia. Show Window constructed with substantial funds are expected to benefit society and the flower growers in Tomohon.
\end{abstract}

One attempt to solve the problems in the provision of various information related to the cultivation of chrysanthemum kulo and riri, then need to be made an integrated system based on information technology, for the models show window, chrysanthemum flower cultivation kulo and riri in Tomohon. With the making of integrated systems based on information technology is expected to provide a variety of information quickly, accurately, easily and accurately.

This study aims to (1) conduct a needs analysis system required in construction and development show window in Tomohon, and (2) make the design of information systems cultivation of varieties of chrysanthemums kulo and riri accordance with the results of the analysis of the needs of the system and (3) making prototypes computer program. Stages of the activities undertaken include the analysis of system requirements and system design.

The information system chrysanthemum flower cultivation kulo and riri is an information system that serves to collect, store, process and present data and information relating to the varieties of chrysanthemums coolies, kulo and riri. Information generated from this system design is based on analysis of information needs that are considered very important by the users. The prototype program is also equipped with navigation models, which can produce a model for conformity assessment show window, a model for determining the capacity of chrysanthemum flower cultivation kulo and riri, the investment model to calculate the cultivation of chrysanthemums, information technology, marketing information (market opportunities). To be able to produce a variety of output produced, the result of design of these systems need to be followed up by implementation so that the system can operate.

\section{Keywords}

Chrysanthemum coolies, and riri, show window, tourism, information technology.

\section{INTRODUCTION}

Tomohon is a hill resort located 22 kilometers east of the provincial capital of Manado in North Sulawesi. Consisting of 35 villages in five sub-districts of West, East, Central, South and North Tomohon. Conditions arable land and air. cool make suitable to cultivate various types of flowers and vegetables. Mount elongated head south is Mount Lokon, in north looming partner named Mountain Empung. Among the two saddle-shaped stretch of embankment along the approximately $2 \mathrm{Km}$. In the saddle that frequent eruption, crater in the region shoot ash and rocks that lasts almost forever. At the foot of Mount Lokon first image of colorful chrysanthemums grown in plantation fields owned by the people. With an area of approximately 90 hectares planted and harvested area of approximately 70 hectares, production reached about seven million flower buds or stalk (Department of Agriculture, Animal Husbandry and Tourism Tomohon 2014)

The easiest way to meet the requirements of the format of writing is to use this document as a template. Then type your text into it flowers produced are well known by the world community due to start organized in 2006 Tomohon International Flower Festival (TIFF) in two years, and now in 2014 Tomohon city government programs for its implementation every year. Tomohon Government programs for flower exports typical of the region, namely Chrysanthemum Kulo (White) to Japan, if the quality of the flowers already meet export standards. Currently the interim government to test planting, to get the flowers that have export standard in the Show Window, Village Kakaskasen II, North Tomohon sub district. Show Window is intended for flower growers in any activities associated with flowers. Development show window of two hectares was built in 2013 and 1.5 hectares will be built in 2015 out of a total of 5 hectares of land which is programmed Tomohon City Government. Show window was built as a showcase that Tomohon as the Flower City and will be the nursery site, learning, cultivation, flower production deployment, as well as used as a tourist spot. Show Window will also become the center for the cultivation of chrysanthemums in the region of Eastern Indonesia. The government also hopes the construction of show window multiplayer cause effects such as a tourist destination. The government will also build the tissue culture laboratory thus becomes the maximum flower cultivation and have export standard. Show Window built is expected to provide benefits for society and the flower growers in Tomohon to strengthen as the City Tomohon. Flower. While this is still conducted trials of planting special flowers Chrysanthemum Kulo and Riri in Show Window area that only grows in Tomohon. Chrysanthemum tomohon larger in size than the chrysanthemum in other areas such as figure 2 , the special so it was named the mascot of Tomohon on the 
implementation of Tomohon International Flower Festival, which is attended by participants from abroad. Now the interest will be the economic driving Tomohon also turned its citizens. $\mathrm{n}$ the Show Window Tomohon in 2013 had been built seven green house that operates as a test site planting chrysanthemums, and in 2015 will be built 3 green house for a total of 10 green houses (Department of Agriculture, Animal Husbandry and Tourism tomohon, 2015), The results of each green house production reached 5 thousand petals one harvest within 3 to 4 months. In addition to adding green house to support the export program, the government also continued to provide guidance to 30 farmer groups interest in Tomohon, in order to develop production.

Currently the Department of Agriculture, Husbandry and Tourism Tomohon as government agencies that have the duty and responsibility in the construction and development of chrysanthemums kulo and riri, yet provides a variety of integrated information about the show window needed to support decision-making in a fast, accurate and accurate. This is because most of the data processing and presentation of information remains piecemeal and manual.

Based on this background, this study didisign to solve problems in the provision of various information related to the chrysanthemum flower cultivation technology kulo and riri with mendisign coolies, modeling of an integrated system based on information technology, for the models show window in the town of Tomohon. With the making of integrated systems based on information technology is expected to provide a variety of information quickly, accurately, easily and accurately.

This study aims to (1) conduct a needs analysis system required in the design and development of a model show window cultivation of chrysanthemums in the town of Tomohon, and (2) make the design of information systems cultivation technologies varieties of chrysanthemums coolies, kulo and riri accordance with the results of the analysis of system requirements and (3) create a prototype of a computer program. Stages of the activities undertaken include the analysis of system requirements and system design. Phase 1 in the first year of the proposed research analysis system needs through observation and interview techniques well with users and with experts in chrysanthemums and by examining documents relating to the technology of chrysanthemum. Analysis of system requirements made to the Department of Agriculture, livestock and Tourism Tomohon, Horticultural Research.

North Sulawesi, Show window chrysanthemums Tomohon, green house cultivation of chrysanthemums in the town of Tomohon. Chrysanthemum Association Tomohon, as well as some businessmen who developed the cultivation of chrysanthemum varieties coolies, kulo and riri. The information system models show window chrysanthemums coolies, kulo and riri is an information system that serves to collect, store, process and present data and information related to the chrysanthemum nursery, learning, cultivation technologies varieties of chrysanthemums coolies,kulo and riri. Information generated from the model show window design is the result of chrysanthemum flower production coolies, kulo and riri in Tomohon and production of exportquality varieties through tissue culture laboratory testing to be built in the area show window of Tomohon.

The problems of this study are as follows.
- How to design models show window for the cultivation of chrysanthemums coolies, kulo and riri based on information technology in Tomohon?

- How to implement the model show window for the cultivation of chrysanthemums coolies, kulo and riri based on information technology in Tomohon using PHP programming language supported by the CSS as a stylist interface and MySQL as database management as well as Java Script as a manager of a data validation?

This research aims to:

- Creating design models show window chrysanthemum flower cultivation, kulo and riri based information technology in the city of Tomohon.

- Implement the modeling show window coolies, chrysanthemum flower cultivation kulo and riri based on information technology by using the PHP programming language supported by the CSS as a stylist interface and MySQL as database management as well as Java Scripps as manager of data validation.

\section{METHODOLOGY}

\subsection{Location and Time}

The location and time of the study conducted in the city of Tomohon and time for 1 year.

\subsection{Stages of Research}

Stages of the planned studies are as in Fig. I.

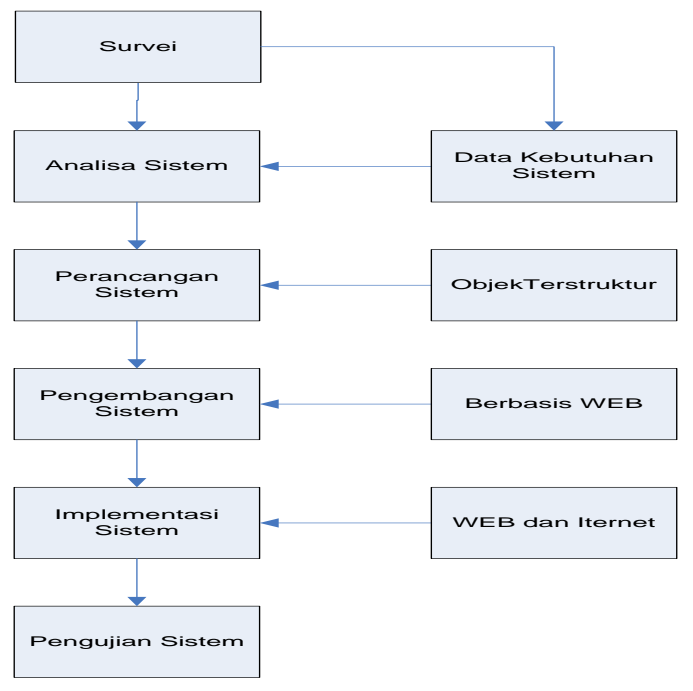

Fig. 1 Block stages of research

Fig. I is a block diagram above illustrates the stages of research that will be conducted during the study.

\subsection{Methods}

The method used for this study is

- Methods of field studies (observation study) and literature (library study). This method is used to identify the problem.

- Interview method, used to determine the system to be built.

- Questionnaire method, used to determine the level of employee participation in providing information. 
- Method of architecture is the method that will be used to describe the system.

- Functional testing using black box to see the results when the system is run if the system can receive data, whether the server is responding and displays information in accordance with the reality on the ground.

- Evaluation through prototype testing program using the interface of respondents with a questionnaire to test the performance whether the system easy to use.

\subsection{Data Collection Techniques}

Data collected by the way,

- Interviews, to obtain data such as system sales, production, finance, raw materials and supplies

- observation, the working mechanism on coconut flour industry

\subsection{Study Design}

The study design consists of:

Literature review

- Studies conducted to collect the reference to be used as the material resources that include: hand books, journals, papers / articles and previous studies associated with the system will designed and applied

- Analysis, design and implementation of applications.

- Analysis of system performance.

- Preparation of reports

\subsection{Research Instrument}

This study requires several instruments to support analysis and research:

- A set of computer or laptop (minimum of an Intel 3)

- Software support: PHP, and MySQL javaskript

- Equipment: modems and printers

\subsection{Analysis System Design}

Some of the analytical tools needed to helpin the analysis in this study are as follows:

- Flow chart, used to analyze the system and program

- Data Flow diagrams, used to analyze the data flow that occurs in the system will be built

- Entity Relationship Diagram, is used to analyze the relationships between the entities in the system to be built

- Use case diagram, used to analyze who is entitled to use the system functions

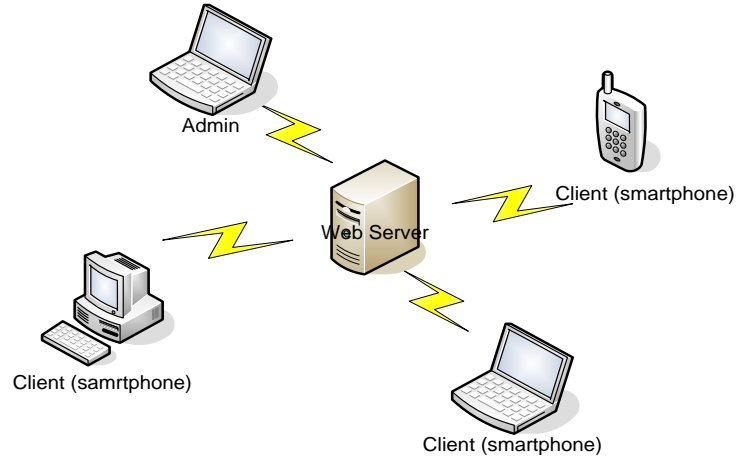

Fig. 2 Block stages of research

The design of the system architecture proposed in this study as in Fig. II. The design of the proposed system is based on a unified conceptual framework as in Fig. 3.

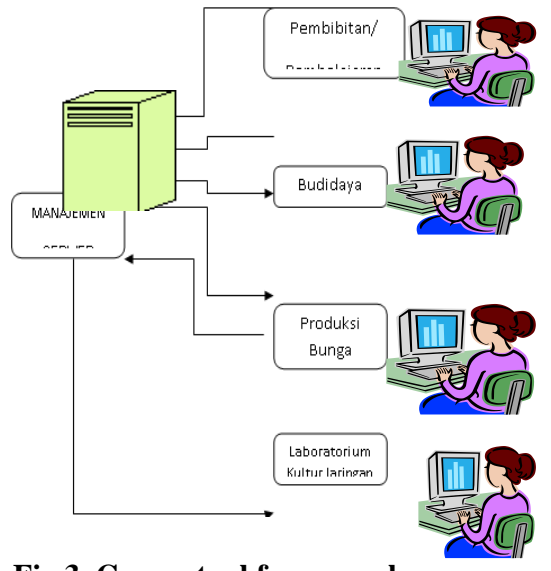

Fig.3. Conceptual framework

This study aims mendisign a model show window for the cultivation of chrysanthemums coolies, kulo and riri based on information technology.

\section{RESULTS AND DISCUSSION}

A. Results

1) Interface: In general based on the needs assessment, the system design can be seen in the main menu system below.

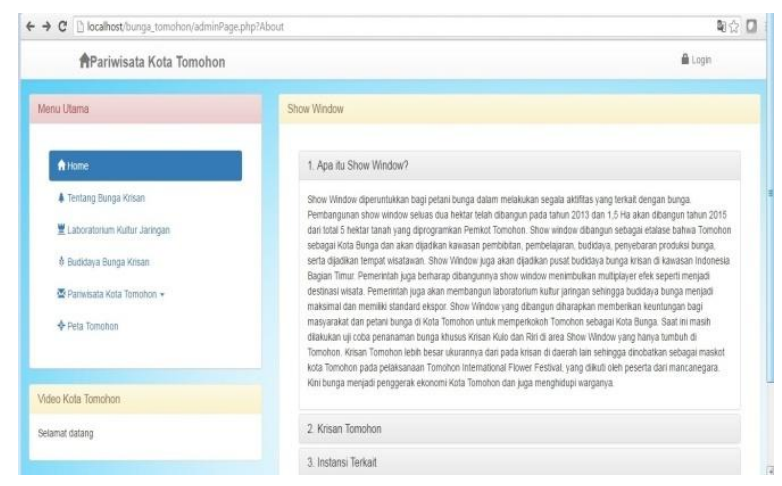

Fig.4. Main Menu 

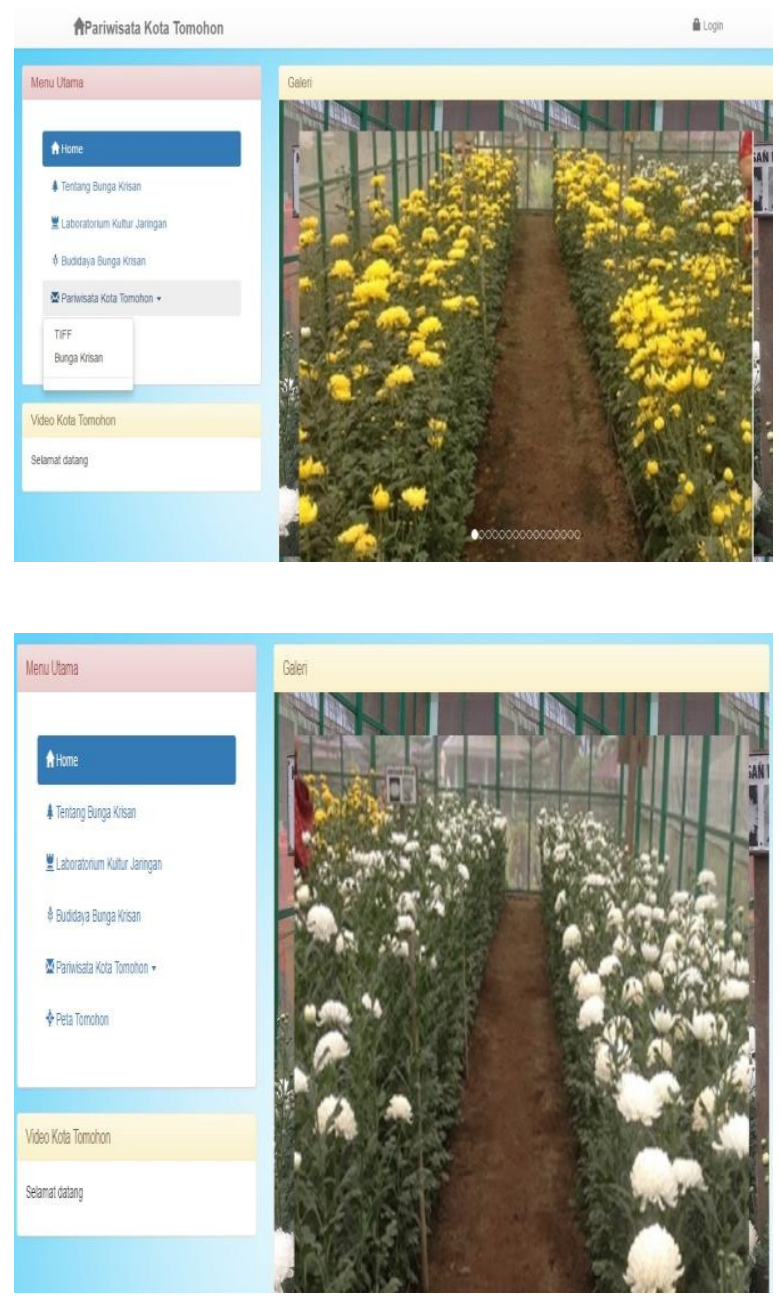

Fig.5. Flower Gallery

2) Testing: Testing the system using blackbox testing and test respondents. Tests on the system were calculated using a black box, which is a method of testing the system or program without considering the structure of the program [13].

\section{Table 1.Test black box}

\begin{tabular}{|l|l|l|l|l|}
\hline Item & $\begin{array}{l}\text { Clas } \\
\text { s } \\
\text { Test }\end{array}$ & $\begin{array}{l}\text { Mec } \\
\text { hani } \\
\text { cal } \\
\text { Test } \\
\text { ing }\end{array}$ & $\begin{array}{l}\text { Expected } \\
\text { results }\end{array}$ & \multicolumn{1}{|c|}{ Test result } \\
\hline & $\begin{array}{l}\text { Aut } \\
\text { hent } \\
\text { icati } \\
\text { on } \\
\text { Ad } \\
\text { min }\end{array}$ & $\begin{array}{l}\text { Blac } \\
\text { Box }\end{array}$ & $\begin{array}{l}\text { Admin can } \\
\text { login, can } \\
\text { add } \\
\text { information. }\end{array}$ & $\begin{array}{l}\text { Checking system } \\
\text { admin login } \\
\text { process, } \\
\text { successful or not, } \\
\text { and then save the } \\
\text { admin session } \\
\text { when the login } \\
\text { process, and shut } \\
\text { down the session } \\
\text { when } \\
\text { administrators } \\
\text { have logged out, } \\
\text { so that the system } \\
\text { can not be opened } \\
\text { again unless must } \\
\text { log back in. } \\
\text { (Successful) }\end{array}$ \\
\hline
\end{tabular}

\begin{tabular}{|l|l|l|lr|l|}
\hline $\begin{array}{l}\text { Aut } \\
\text { hetif } \\
\text { user } \\
\text { user }\end{array}$ & $\begin{array}{l}\text { Blac } \\
\mathrm{k} \\
\text { Box }\end{array}$ & $\begin{array}{l}\text { Users can } \\
\text { access a } \\
\text { menu of } \\
\text { allowed }\end{array}$ & $\begin{array}{l}\text { The system } \\
\text { receives the } \\
\text { requested user to } \\
\text { thesired } \\
\text { information } \\
\text { (successful) }\end{array}$ \\
\hline $\begin{array}{l}\text { Data } \\
\text { proc } \\
\text { essi } \\
\text { ng }\end{array}$ & $\begin{array}{l}\text { Blac } \\
\mathrm{k} \\
\text { Box }\end{array}$ & $\begin{array}{l}\text { Admin can } \\
\text { perform } \\
\text { data } \\
\text { processing } \\
\text { on the } \\
\text { master and } \\
\text { booking }\end{array}$ & $\begin{array}{l}\text { The system can } \\
\text { display, add data } \\
\text { from admin } \\
\text { (sucsesfull) }\end{array}$ \\
\hline
\end{tabular}

Table. I is a summary of the results of blackbox testing method to test the entire system such as logins and data processing with the intended results

Table 2. List of answer question

\begin{tabular}{|l|l|l|l|l|l|l|}
\hline \multirow{2}{*}{ Item } & \multicolumn{2}{|c|}{ Question } & \multicolumn{5}{|c|}{ Score Answers } \\
\cline { 3 - 7 } & & 5 & 4 & 3 & 2 & 1 \\
\hline 1 & $\begin{array}{l}\text { This app is } \\
\text { easy to use }\end{array}$ & 5 & 3 & 2 & & \\
\hline 3 & $\begin{array}{l}\text { This app } \\
\text { makes it easy } \\
\text { to get } \\
\text { information }\end{array}$ & 6 & 2 & 2 & & \\
\hline $\begin{array}{l}\text { The } \\
\text { application is } \\
\text { appropriate to } \\
\text { support } \\
\text { tourism in the } \\
\text { city tomohon }\end{array}$ & 5 & 4 & 1 & & \\
\hline
\end{tabular}

The results of data analysis for the expression of one show as much as $86.00 \%$ of respondents stated that these applications are easy to use. For the second statement shows as much as $73.33 \%$ of respondents said that application makes it easy to get information. For statement 3 show as much as $88.00 \%$ of respondents stated that the application is appropriate to support the tourism town of Tomohon.

\section{CONCLUSION}

The conclusion of this study is.

- Analysis and system requirements for the design and development of models show window chrysanthemum flower cultivation at Tomohon and manufacture prototype computer program for information technology systems of cultivation varieties of chrysanthemums can be met.

- The design of integrated systems to be built with every admin has access rights individually.

- Test the black box showed that the application responds to what is input, process and information as expected.

- Test the black box showed that the aplication responds to input,process and information as expected.

- Later models show window information system chrysanthemum will produce a system that serves to collect, store, process and present data and information related to the chrysanthemum nursery,cultivation technologies varieties of chrysanthemums kulo and riri in Tomohon. 


\section{REFERENCES}

[1] Agency for Agricultural Research Center Horticultural Research and Development; Prosedural for Seed Production and seed breeder Core chrysanthenum, Agency for Agricultural Research Center Horticultural Research Development, 2003.

[2] The Agency for Agricultural Research, the Research Institute for Agro-climate and Hydrology; Identification and Evaluation of Potential Land to Support Prima Tani in the village Kakaskasen Two - district. North Tomohon, Tomohon; Department of Agriculture, Plantation, Livestock and Fisheries Tomohon, 2006 Annual Report; 2007.

[3] Ibrahim Kenneth E Kendall, Analisis \& Perancangan Sistem, Printice Hall, New JerseKendall, Kenneth E.;1992; System Analysis and Design 2nd Edition; Prentice Hall; New Jersey y, 2002 (terjemahan)...

[4] Jumin, H.B. 2002, Agronomi. Fajar Interpratama Offset, Jakarta.

[5] Kenneth E Kendall, Analisis \& Perancangan Sistem, Printice Hall, New JerseKendall, Kenneth E.;1992; System Analysis and Design 2nd Edition; Prentice Hall; New Jersey y, 2002 (terjemahan).
[6] Kurniawan Budiarto, S. Yoyo., M. Ruud dan W. Sri, Budidaya Krisan; 2006.

[7] Manish Mittal, Gaurav Tripathi, Deepa Chauhan and Atul Agarwal, Green House Monitor and Control Using Wireless System Network, VSRD-IJEECE, Vol. 2 (6), 2012, 337-345. Uttar Pradesh, INDIA..

[8] Sinar Tani, 2009. BALITHI Menuju Kemandirian Tanaman Hias Indonesia. Edisi 2 - 8 September 2009 No. 3319 Tahun

[9] Sutarman. 2003. Membangun Aplikasi Web dengan PHP dan MySQL. Seri Pemrograman Web. Penerbit Graha Ilmu. Jakarta.

[10] Jogiyanto, Analisis dan Disain Sistem, Penerbit Andi, 2005

[11] M. Raymond Jr, G. D. Scell, Sistem Informasi Manajemen, New Jersey, Prentice Hall, (terjemahan) 2004

[12] S. Rosa, Rekayasa Perangkat Lunak, Bandung, Penerbit Modula, 2011

[13] R. Pressman, Rekayasa Perangkat Lunak, Andi, 2002. 